\title{
Odpowiedzialność za szkodę wyrządzoną przez produkt niebezpieczny żywnościowy pierwotny i przetworzony. Wybrane problemy
}

Motto

„Odpowiedzialność cywilna jest obok własności jednym z filarów, na jakich opiera się system prawa cywilnego. Można sobie wyobrazić (chociaż z wielka trudnościq) taki system prawny, w którym nie wystęuje umowa, nie można natomiast mówić o prawie cywilnym bez odpowiedzialności."

A. Stelmachowski Zarys teorii prawa cywilnego

\section{Wstęp}

Tradycyjnie, w systemach prawa cywilnego wyróżnia się dwa reżimy odpowiedzialności za szkodę, reżim ex delicto i reżim ex contractu, przy czym w ramach drugiego reżimu wyróżnia się dodatkowo odpowiedzialność na zasadach ogólnych oraz szczególną odpowiedzialność kontraktową (rękojmia, gwarancja). Klasyfikacja ta nie jest jednak bezdyskusyjna. $Z$ jednej strony występuje reżim o jednolitym zakresie, ściśle wyznaczonym, jakim jest reżim ex contractu, z drugiej zaś wiele różnorodnych rodzajów, których jedyną wspólną cechą i to negatywną jest to, iż nie jest to odpowiedzialność ex contractu ${ }^{2}$. W pewnych sytuacjach roszczenie o naprawienie szkody może być oparte na jednej lub drugiej podstawie, przy czym poszkodowany nie może występować o dwa odszkodowania, za szkodę należy się bowiem jedno odszkodowanie.

Od kilkudziesięciu lat obserwowany jest rozwój masowej produkcji różnorodnych produktów, w tym produktów dawniej w ogóle nieznanych, a także upowszechnia się sprzedaż gotowych produktów. Pojawiają się nowe technologie produkcji, stosuje się przy tej produkcji nowe surowce i półfabrykaty, będące w dużej mierze rezultatem długoletnich badań. Produkty stają się coraz bardziej złożone, co

Uniwersytet Warszawski.

Por. A. Ohanowicz, J. Górski, Zarys prawa zobowiązań, Warszawa 1970, s. 51. Na nieścisłość tego podziału wskazuje też W. Warkałło, Odpowiedzialność odszkodowawcza. Funkcje, rodzaje, granice. Warszawa 1972, s. 79-81. 
powoduje, że trudniejszym jest zapewnienie skutecznej kontroli bezpieczeństwa, a w konsekwencji zwiększa się prawdopodobieństwo zaistnienia nowych wad $^{3}$. W sposób szczególny jest to widoczne na rynku produktów żywnościowych, gdzie obok produktów znanych od wieków pojawia się wiele środków spożywczych wytworzonych z wykorzystaniem nowych technologii, jak chociażby żywność genetycznie zmodyfikowana, żywność pochodząca z klonowania, żywność wytwarzana z wykorzystaniem nanotechnologii, nowe suplementy diety uzyskiwane często w drodze procesów chemicznych. Rozwój ten może ułatwiać życie i zwiększa możliwości działalności człowieka, z drugiej jednak strony pociąga za sobą różnego rodzaju niebezpieczeństwa i stwarza nowe, dawniej nieznane, zagrożenia ${ }^{4}$.

W sposób bardzo intensywny rośnie też globalna wymiana handlowa, która powoduje, iż produkt wytworzony w jednym miejscu jest sprzedawany w zupełnie innym miejscu świata. Producenci żywności, działając pod presją globalnej konkurencji i dążąc do optymalizacji zysków, podejmują działania zmierzające do obniżania kosztów produkcji, co wpływa na jakość wytwarzanej żywności. Jednocześnie prowadzą aktywne działania marketingowe, mające przyczynić się do zwiększania obrotów, co nawet przeciętnemu konsumentowi utrudnia odróżnienie „dobrej” od „,złej” jakości żywności.

Tak szybki rozwój produkcji i handlu oraz związanych z tym niebezpieczeństw, które coraz częściej zaczęły dotykać bezpośrednio każdego człowieka, spowodowały, że tradycyjne rozwiązania prawne w zakresie odpowiedzialności odszkodowawczej stały się nieskuteczne

$\mathrm{Z}$ jednej strony, reżim kontraktowy ograniczany jest bowiem zasadą privity of contract, stosownie do której reżim ten nie ma zastosowania w sytuacji, gdy osobą poszkodowaną nie jest strona kontraktu, nabywca, lecz osoby trzecie - członkowie rodziny, goście lub przypadkowe osoby (zasada privity w aspekcie horyzontalnym) lub gdy zbywca nie jest producentem, co jest regułą (zasada privity w aspekcie wertykalnym $)^{6}$. W związku z powyższym, w oparciu o ten reżim niemożliwe było dochodzenie odszkodowań przez osoby poszkodowane, które nie były związane umową z producentem ${ }^{7}$.

3 E. Łętowska, Ustawa o ochronie niektórych praw konsumentów, komentarz, Warszawa 2000, s. 111.

4 E. Kremer, Odpowiedzialność za zobowiązania związane z prowadzeniem gospodarstwa rolnego, Kraków 2004, s. 113.

5 E. Łętowska, Ustawa o ochronie..., s. 111.

6 A. Janik, Nowe tendencje w dziedzinie odpowiedzialności za produkt (uwagi prawno-porównawcze), „Państwo i Prawo" 1984, nr 8, s. 73.

$7 \quad$ Warto wskazać, że dla uzyskania lepszej ochrony dla poszkodowanych w poszczególnych państwach próbowano złagodzić surowość tej zasady różnymi sposobami. W doktrynie i orzecznictwie sądów niemieckich i austriackich proponowano rozszerzyć podmiotowe granice stosunku zobowiązaniowego poprzez konstrukcję umowy ze skutkiem wobec osoby trzeciej. W koncepcji tej przyjmowano, że pomiędzy producentem a ostatecznym nabywcą zawierana jest w oparciu o zaufanie umowa o ochronnym działaniu (nabywca, kupując produkt, okazuje zaufanie producentowi, a zapłatę za towar od nabywcy faktycznie otrzymuje producent). Zob. A. Janik, Nowe tendencje..., s. 73. W USA przyjmowano zasadę, że uprawnienia z rękojmi przechodzą na każdoczesnego legal- 
Z drugiej strony, oparcie się o reżim deliktowy stwarzało problemy z koniecznością przypisania sprawcy szkody winy (co najmniej niedbalstwa) i udowodnienia jej przed sądem, co jest zabiegiem trudnym, pozwalającym niejednokrotnie producentowi uniknąć odpowiedzialności ${ }^{8}$. Wysiłki orzecznictwa zmierzały do złagodzenia tych trudności. Osiągano to przez różne formy obiektywizacji winy. Podnoszono miarę należytej staranności, tworzono koncepcję winy anonimowej (organizacyjnej), przyjmowano domniemania co do winy producenta, uznawano, że w razie wątpliwości rozstrzygać należy na korzyść poszkodowanego ${ }^{9}$. Dążąc do obiektywizacji odpowiedzialności deliktowej i udzielenia jak najszerszej ochrony poszkodowanym, reguły odpowiedzialności deliktowej zostały na tyle zmienione, iż można mówić o ewolucji ku nowemu rodzajowi odpowiedzialności odszkodowawczej, tj. odpowiedzialności za szkodę wyrządzoną przez produkt niebezpieczny.

Niedostosowanie tradycyjnych reżimów odpowiedzialności do potrzeb wynikających z intensywnego rozwoju produkcji i handlu masowego stanowiło zatem główny impuls do wprowadzenia regulacji prawnej odpowiedzialności za produkt.

Normatywne usankcjonowanie tego rodzaju odpowiedzialności ma przyczyniać się przede wszystkim do lepszej ochrony konsumenta, który jest podmiotem słabszym ekonomicznie.

\section{Ogólna charakterystyka odpowiedzialności za produkt}

Odpowiedzialność za produkt jest odpowiedzialnością odszkodowawczą, niezależną od winy za spowodowanie szkody, opartą na zasadzie ryzyka, nieuwarunkowaną istnieniem wcześniejszej umowy.

nego nabywcę przedmiotu. Stworzono tam też teorię tzw. łącznego funduszu gospodarstwa domowego, gdzie podstawowym założeniem było przyjęcie, że zakupy dokonywane przez jednego członka rodziny są przeznaczone dla wszystkich członków tego gospodarstwa. Zob. M. Jagielska, Odpowiedzialność za produkt-dostosowanie prawa wewnętrznego państw Unii Europejskiej do wymogów dyrektywy 374/85, Kraków 1999, s. 41. W prawie francuskim i belgijskim do przełamywania zasady privity of contract wykorzystywana była konstrukcja action direct. Jej najważniejszym założeniem jest przywiązanie uprawnień płynących z tytułu rękojmi do rzeczy. Każdoczesny nabywca towaru ma prawo kierować swe roszczenia przeciwko któremukolwiek z wcześniejszych uczestników łańcucha sprzedaży, z producentem włącznie. Do niego należy też wybór osoby, przeciwko której wystapi. Sądy francuskie rozszerzyły stosowanie action direct również na roszczenia kontraktowe oparte na zasadach ogólnych, o ile celem umowy było dostarczenie towaru, który okazał się wadliwy. Por. M. Jagielska, Odpowiedzialność..., s. 215.

8 R. Szostak, Zakres odpowiedzialności za produkt, „Radca Prawny” 1995, nr. 1, s. 7.

9 W krajach common law rozwiązania poszły jeszcze dalej niż domniemanie winy, przyjęto tam strict liability, która pomija winę jako przesłankę odpowiedzialności. Nie oznacza to jednak odpowiedzialności za sam skutek. Producent nie odpowiada za to, że jego produkt wyrządził szkodę, lecz za to, że szkoda powstała wskutek wad towaru. Rygoryzm tego rozwiązania spowodował drastyczny wzrost wysokości składek przy ubezpieczeniu odpowiedzialności cywilnej producentów, reakcją była podwyżka cen produktów i faktyczne przerzucenie ciężaru wzrostu kosztów na nabywców. Tym niekorzystnym skutkom starano się przeciwdziałać poprzez ograniczanie strict liability do tych przypadków, gdy skutkiem wady były wyłącznie szkody na osobie. Powrócono również do formuły zawinionego przyczynienia się poszkodowanego, traktując je jako przesłankę ograniczająca odpowiedzialność producenta. Por. A. Janik, Nowe tendencje..., s.76-76. 
Najogólniej rzecz ujmując, deliktem decydującym o przypisaniu tej odpowiedzialności jest wprowadzenie do obrotu produktu niebezpiecznie wadliwego ${ }^{10}$. Podmiotem odpowiedzialnym jest producent, a podmiotem objętym tą ochroną jest każdy, kto doznał szkody na skutek wadliwości produktu ${ }^{11}$. Odpowiedzialność ta dotyczy szkód następczych, nieobjętych tradycyjną odpowiedzialnością za wady produktu $^{12}$. Nie ma ona charakteru absolutnego, producent może uwolnić się od odpowiedzialności specyficznymi dla odpowiedzialności za produkt przesłankami egzoneracyjnymi ${ }^{13}$. Odpowiedzialność za produkt nie narusza tradycyjnych sposobów dochodzenia roszczeń. Powstaje z mocy samego prawa i nie można jej ani wyłączyć, ani ograniczyć.

Przepisy o odpowiedzialności za produkt, opierając odpowiedzialność producenta na zasadzie ryzyka, wymuszają na nim konieczność dołożenia szczególnej staranności, tak by produkt nie stwarzał niebezpieczeństwa wyrządzenia szkody konsumentowi.

\section{Zarys rozwoju odpowiedzialności za produkt}

Początki odpowiedzialności deliktowej niezależnej od winy należy wiązać z odpowiedzialnością absolutną, strict liability, która rozwinęła się w latach 60-tych w Stanach Zjednoczonych ${ }^{14}$. Na początku lat 70-tych próbę recepcji amerykańskich wzorów odpowiedzialności za produkt podjęto w ramach EWG. Zamiarem inicjatorów było ujednolicenie odpowiedzialności za produkt oraz stworzenie korzystniejszych dla poszkodowanych podstaw dochodzenia roszczeńn ${ }^{15}$.

Regulacja prawna odpowiedzialności za produkt wdrożona została do prawodawstwa unijnego dyrektywą 85/374/EWG z dnia 25 lipca 1985 r. w sprawie zbliżenia przepisów ustawowych, wykonawczych i administracyjnych państw członkowskich dotyczących odpowiedzialności za produkty wadliwe (dalej „dyrektywa 85/374).

W polskim prawodawstwie odpowiedzialność za szkodę wyrządzoną przez produkt niebezpieczny uregulowana została $\mathrm{w}$ art. $449^{1}-449^{11}$ kodeksu cywilnego. Wprowadzenie tych przepisów do kodeksu cywilnego ustawą z dnia 2 marca 2000 r.

Pewne wątpliwości związane są z samą nazwą stosowaną na określenie tego typu odpowiedzialności. W literaturze spotyka się takie określenia jak „odpowiedzialność producenta”, odpowiedzialność „za niebezpiecznie wadliwy produkt”, „za produkt niebezpieczny”, „za produkt wadliwy” „za wyprodukowanie rzeczy z wadami” czy „o cechach niebezpiecznych". Mimo, iż za każdym razem zdarzenie, z którym wiąże się odpowiedzialność, jest określone inaczej, w każdym przypadku chodzi o ten sam typ odpowiedzialności.

11 Przy tym wadliwość ta jest zobiektywizowana i polega na posiadaniu przez produkt cech, które powoduja, iż nie zapewnia on bezpieczeństwa, jakiego można by od niego oczekiwać.

12 W tym zakresie zastosowanie znajdują przepisy dotyczące rękojmi i niezgodności towaru z umową.

13 Ryzyko rozwoju (tj. wykazanie, że stan techniki w chwili wprowadzania do obrotu nie dawał możliwości wykrycia wady), czy brak cechy niebezpiecznej produktu w chwili wprowadzenia na rynek.

14 Szerzej zob. E. Bagińska, Odpowiedzialność za produkt w USA, Toruń 2000, s. 65-80.

15 A. Janik, Nowe tendencje..., s. 75. 
o ochronie niektórych praw konsumentów oraz o odpowiedzialności za szkodę wyrządzoną przez produkt niebezpieczny stanowiło implementację dyrektywy 85/374.

Należy jednak podkreślić, że implementacja dyrektywy, pomimo iż stanowiła bezpośrednią przyczynę uregulowania odpowiedzialności za szkodę wyrządzoną przez produkt niebezpieczny, w istocie stanowiła ukoronowanie procesu wyodrębniania się odpowiedzialności za produkt dokonywanego przez polską judykaturę już w latach siedemdziesiątych. Sąd Najwyższy, opierając odpowiedzialność za szkody wyrządzone przez produkt wadliwy na przepisach art. $415 \mathrm{i} \mathrm{n.} \mathrm{kc.,} \mathrm{w} \mathrm{dro-}$ dze wykładni „dostosowywał” przesłanki tej odpowiedzialności w celu zapewnienia rzeczywistej ochrony poszkodowanemu. W orzecznictwie nie tylko uznano za czyn niedozwolony wprowadzenie niebezpiecznych towarów do obrotu ${ }^{16}$, ale w drodze faktycznego domniemania uznano istnienie winy po stronie osoby, co do której istnieje prawdopodobieństwo, iż ponosi ona odpowiedzialność za szkodę. Przyjęto przeniesienie na nią ciężaru dowodu, co w praktyce zwalniało poszkodowanego z obowiązku udowodnienia winy, która jest przesłanką odpowiedzialności deliktowej z art. $415 \mathrm{kc}$. W ramach odpowiedzialności osób prawnych zaczęto przyjmować koncepcję „winy bezimiennej” (anonimowej), gdy przesłanką odpowiedzialności jest wina organu lub podwładnego, a także ,winy organizacyjnej”, tj. odpowiedzialności za wadliwą organizację, w następstwie czego nastąpiło wyrządzenie szkody ${ }^{17}$. Implementacja dyrektywy 85/374 nie oznacza zatem, w odniesieniu do potencjalnego zakresu ochrony, radykalnej nowości. Nowości należy raczej upatrywać w ułatwieniu i uproszczeniu realizacji odpowiedzialności na płaszczyźnie dowodowej ${ }^{18}$.

Podkreślić jednak trzeba, że treść dyrektywy 85/374, która zawiera bardzo szczegółowe unormowania niektórych kwestii (np. wysokość tzw. szkód banalnych, ograniczenie w czasie odpowiedzialności) przesądziła o kształcie przyjętej przez polskiego ustawodawcę regulacji odpowiedzialności za szkodę wyrządzoną przez produkt niebezpieczny.

\section{Odpowiedzialność za produkt niebezpieczny w prawie żywnościowym}

Biorąc po uwagę zarówno powszechność umów dotyczących nabywania produktów żywnościowych przez konsumentów, ich przeciętną wartość i formę zawierania umowy, jak również to, że osoba poszkodowana nie musi być, i często nie jest, tą samą osobą, która produkt żywnościowy nabyła, za niewątpliwe uznać należy, że

Wyrok SN z dn.6.8.1981 r. I CR 219/81,OSPiKA 1983, z. 2, poz. 23c, gdzie w sprawie, w której powód doznał szkody na skutek spożycia ciasta ze znajdującą się tam szpilką, SN stwierdził "Wprowadzenie przez producenta do obrotu towaru mogącego stanowić - ze względu na obecność ciał obcych - zagrożenie dla zdrowia lub życia stanowi czyn niedozwolony w rozumieniu art. $415 \mathrm{kc} . "$

Tak J. Skapski, Odpowiedzialność za wadliwe produkty. Wprowadzenie, KPP 1995, z.4, s. 585; E. Łętowska, Ustawa o ochronie..., s. 113.

E. Łętowska, Ustawa o ochronie..., s. 113. 
dochodzenie roszczeń odszkodowawczych w oparciu o reżim ex contractu w przypadku szkody powstałej na skutek spożycia żywności jest utrudnione. $Z$ drugiej strony, nadmiernym utrudnieniem dla przeciętnego konsumenta jest konieczność wykazania winy producenta żywności, co stanowi przeszkodę w dochodzeniu roszczeń w oparciu o reżim ex delicto. W związku z powyższym, to właśnie odpowiedzialność za szkodę wyrządzoną przez produkt niebezpieczny powinna mieć podstawowe znaczenie przy dochodzeniu roszczeń z tytułu szkody wyrządzonej niebezpiecznym produktem żywnościowym.

Stwierdzenie takie znajduje uzasadnienie zarówno w krajowych, jak i w unijnych przepisach prawa żywnościowego. W treści art. 21 rozporządzenia Parlamentu Europejskiego i Rady nr 178/2002 ustanawiającego ogólne zasady i wymagania prawa żywnościowego, powołującego Europejski Urząd ds. Bezpieczeństwa Żywności oraz ustalającego procedury w sprawie bezpieczeństwa żywności ${ }^{19}$ (dalej „Ogólne Prawo Żywnościowe”), wyraźnie stwierdza się, że przepisy prawa żywnościowego pozostają bez uszczerbku dla dyrektywy 85/374 EWG. Podobnie w treści ustawy z 25 sierpnia 2006 r. o bezpieczeństwie żywności i żywienia ${ }^{20}$, w art. 95 wprost wskazuje się, że odpowiedzialność za szkodę spowodowaną przez żywność ponoszona jest na zasadach określonych w przepisach kodeksu cywilnego dotyczących odpowiedzialności za szkodę wyrządzoną przez produkt niebezpieczny. Tym samym zarówno unijne, jak i krajowe prawo żywnościowe w zakresie odpowiedzialności cywilnej „wpisuje się” w zharmonizowane zasady odpowiedzialności za szkodę wyrządzoną przez produkt niebezpieczny, mające na celu szczególną ochronę konsumenta ${ }^{21}$.

Przywołane przepisy stanowią niejako sugestię prawodawcy, zarówno unijnego, jak i krajowego, aby to odpowiedzialność za produkt niebezpieczny traktować jako podstawowy sposób dochodzenia roszczeń odszkodowawczych w przypadku szkód wyrządzonych przez żywność. Stwierdzić zatem należy, że pomimo iż zasady odpowiedzialności odszkodowawczej nie zostały uregulowane w prawie żywnościowym i nie można ich zaliczyć do zakresu prawa żywnościowego, to jednak prawodawca uznaje, że obok odpowiedzialności administracyjnej i karnej, odgrywających kluczową rolę w realizacji celów prawa żywnościowego ${ }^{22}$, także ten rodzaj odpowiedzialności odszkodowawczej ma znaczenie w realizacji tych celów.

19 Dz.U. UE L 31 z 1.2.2002, s. 1

20 Dz.U. Nr 171, późn. 1225 ze zm.

21 M. Korzycka-lwanow, Żywność w kontekście odpowiedzialności cywilnej za szkodę wyrządzona przez produkt niebezpieczny, (w:) Współczesne problemy prawa prywatnego. Księga pamiątkowa ku czci Profesora Edwarda Gniewka, (red.) P. Machnikowski, J. Gołaczyński, Warszawa 2010, s. 296.

Szerzej zobacz P. Wojciechowski, Z problematyki odpowiedzialności w prawie żywnościowym, „Przegląd Prawa Rolnego" 2011, nr 1, s. 68. 


\section{A. Pojęcie produktu a pojęcie żywności}

Zgodnie z definicją zawartą w kodeksie cywilnym, która jest odzwierciedleniem definicji z dyrektywy 374/85, produktem jest każda rzecz ruchoma, choćby została połączona $\mathrm{z}$ inną rzeczą. Za produkt uważa się również zwierzęta i energię elektryczną (art. $449^{1} \S 2 \mathrm{kc}$.). Polski ustawodawca nie pozostawia wątpliwości, iż produktem może być (poza energią) wyłącznie przedmiot materialny będący rzeczą ruchomą lub przedmiotem, który był rzeczą ruchomą, jednak na wskutek połączenia $\mathrm{z}$ inną rzeczą stał się jej częścią składową. Ponadto, w związku z tym, iż zwierzęta w polskim prawodawstwie nie są zaliczane do rzeczy, ustawodawca wyraźnie wskazał, że także zwierzęta objęte są zakresem definicji produktu ${ }^{23}$. Dla uznania rzeczy za produkt zupełnie nie ma znaczenia charakter tej rzeczy, jej przeznaczenie oraz sposób korzystania z niej.

Pojęcie żywności zdefiniowane zostało w Ogólnym Prawie Żywnościowym. Żywność oznacza ,jakiekolwiek substancje lub produkty, przetworzone, częściowo przetworzone lub nieprzetworzone, przeznaczone do spożycia przez ludzi lub któ-

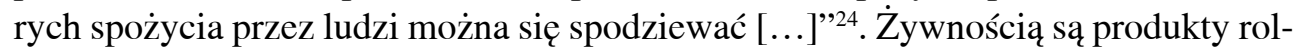
ne przeznaczone do spożycia przez ludzi lub których spożycia można się spodziewać $^{25}$, a zatem wytworzone w ramach działalności rolniczej płody ziemi, produkty hodowli i rybołówstwa, które określić można mianem produktów żywnościowych pierwotnych. Żywnością są także wszelkiego rodzaju produkty, przeznaczone do spożycia lub których spożycia można się spodziewać, uzyskane na skutek przetworzenia produktów pierwotnych oraz produkty uzyskane w drodze procesów chemicznych, niepochodzące z działalności rolniczej (np. niektóre suplementy diety) ${ }^{26}$, które ogólnie nazwać można produktami żywnościowymi przetworzonymi.

Wobec wyżej przytoczonych definicji produktu i żywności nie ma najmniejszych wątpliwości, iż pojęcie ,produkt” obejmuje swoim zakresem wszelkiego rodzaju żywność, w tym produkty żywnościowe pierwotne i przetworzone.

W tym miejscu warto zauważyć, że w pierwotnym brzmieniu dyrektywy 85/374 istniała możliwość wyłączenia przez poszczególne państwa członkowskie z zakresu definicji produktu ,ziemiopłodów, produktów hodowlanych oraz produktów ry-

23 Wynika to $z$ ustawy $z$ dnia 21 sierpnia $1997 \mathrm{r}$. o ochronie zwierząt.

24 Art. 2 rozporządzenia 178/2002/WE, dalej w przywołanej definicji wymienione zostały te produkty i substancje, które zalicza się do pojęcia żywności, pomimo mogących pojawiać się wątpliwości oraz substancje i produkty, które żywnością nie sa, chociaż można spodziewać się ich spożycia (np. produkty lecznicze, pasze).

$\mathrm{Na}$ temat pojęcia produktu rolnego zob.: M. Korzycka-Iwanow, Z problematyki pojęć prawnych produktu rolnego i żywności, przy uwzględnieniu suplementu diety, (w:) Rozprawy i Studia, Księga pamiątkowa dedykowana profesorowi Aleksandrowi Lichorowiczowi, (red.) E. Kremer. Z. Truszkiewicz, Kraków 2009, s. 129 i n. oraz przywołana tam literatura.

Szerzej na temat suplementu diety zob.: M. Korzycka-Iwanow, Z problematyki..., s.134; M. Korzycka-Iwanow, M. Zboralska, Never-ending debate on food supplements: harmonization or disharmonization of the law?, EFFLR, 2010/3, s. 124; P. Wojciechowski, Introduction of a food supplement into the Polish market, „Rivista di Diritto Alimentare" 2010, nr 1, s. 26. 
bołówstwa z wyłączeniem produktów poddanych jakiemukolwiek procesowi przetwórczemu" (art. 2 Dyrektywy przed zmianą) ${ }^{27}$, a zatem produktów żywnościowych pierwotnych. Potrzebę wyłączenia produktów żywnościowych pierwotnych z zakresu definicji produktu uzasadniano m.in. tym, że w produktach tych szczególnie często występują trudne do wykrycia wady powodowane przez ich przechowywanie albo przez czynniki pozostające poza kontrolą producenta (rolnika), np. przez zatrucie środowiska naturalnego. Regulacja ta stanowiła jednak przedmiot krytyki. Biorąc pod uwagę częstotliwość korzystania przez konsumentów z produktów żywnościowych pierwotnych, jak i charakter szkód, jakie mogą powodować, samo wyłączenie z zakresu definicji produktów żywnościowych pierwotnych w sposób istotny zawężało zakres ochrony dla osób poszkodowanych. Problematyczne było także rozumienie użytego w wyłączeniu pojęcia ,,procesu przetwórczego" ${ }^{28}$. Impulsem do podjęcia prac mających na celu objęcie odpowiedzialnością za produkt również produktów żywnościowych pierwotnych były nasilające się przypadki zatruć bakteryjnych związanych ze spożywaniem produktów żywnościowych pierwotnych oraz pojawienie się choroby wściekłych krów i skażeń żywności dioksynami ${ }^{29}$. W efekcie tych prac, dyrektywą 1999/34/WE z 10 maja 1999 r. o zmianie dyrektywy 85/374 wyłączono powyżej wskazaną możliwość, zobowiązując państwa członkowskie do dokonania zmian w przepisach krajowych w tym zakresie do dnia 4 grudnia 2000 roku.

\section{B. Pojęcie produktu niebezpiecznego żywnościowego}

W związku z tym, że w ramach omawianego reżimu odpowiedzialność ponoszona jest wyłącznie za szkodę wyrządzoną przez produkt niebezpieczny, kluczowe znaczenie ma zdefiniowanie pojęcia produktu niebezpiecznego żywnościowego.

Bezpieczeństwo produktu w regulacji dotyczącej odpowiedzialności za szkodę wyrządzoną przez produkt niebezpieczny określone zostało poprzez odwołanie się do celu ochrony - „oczekiwań” związanych z bezpieczeństwem produktu przy jego „normalnym” użyciu. Produkt jest niebezpieczny, gdy „nie zapewnia bezpieczeństwa, jakiego można oczekiwać, uwzględniając normalne użycie produktu" (art. $449^{1} \S 3 \mathrm{kc}$. .).

Ustawodawca daje pewne wskazówki interpretacyjne. Na stopień bezpieczeństwa rzutują wszystkie okoliczności z chwili wprowadzenia go do obrotu, a zwłasz-

Z możliwości takiej skorzystała większość państw członkowskich. Wyjątkiem były Luksemburg, Szwecja i Finlandia. Zob. E. Bagińska, Nowe unormowanie odpowiedzialności cywilnej za produkt, „Przegląd Sądowy” 2009, nr 9, s. 51.

W dyrektywie 85/374 użyto innego sformułowania niż w traktatowej definicji produktu rolnego, poza tym istniała wyraźna różnica pomiędzy treścią preambuły a art. 2 dyrektywy. 1999 , s. 108. 
cza sposób zaprezentowania go na rynku oraz wszystkie objaśnienia, informacje, instrukcje (art. $449^{1} \S 3 \mathrm{kc}$.).

Oczekiwania dotyczące poziomu bezpieczeństwa produktu mogą być kształtowane normatywnie. W sposób szczególny dotyczy to żywności, w odniesieniu do której istnieją szczegółowe regulacje prawne normujące kwestię uznania jej za niebezpieczną.

Ustawodawca unijny wprost zdefiniował, że niebezpieczną jest żywność, jeżeli uważa się, że: jest szkodliwa dla zdrowia lub nie nadaje się do spożycia przez ludzi (art. 14 ust 2 Ogólnego Prawa Żywnościowego).

W Ogólnym Prawie Żywnościowym określone zostały szczegółowe zasady dokonywania oceny niebezpieczeństwa żywności. Wskazane zostało przede wszystkim, że przy ustalaniu, czy żywność jest niebezpieczna, należy mieć na względzie: zwykłe okoliczności korzystania z żywności przez konsumenta oraz wykorzystywania jej na każdym etapie produkcji, przetwarzania i dystrybucji, a także informacje przeznaczone dla konsumenta, z uwzględnieniem informacji na etykiecie oraz inne informacje zwykle dostępne dla konsumenta dotyczące unikania konkretnych negatywnych skutków dla zdrowia związanych z daną żywnością lub rodzajem żywności $^{30}$. Poza tym doprecyzowane zostało, że przy ustalaniu, czy żywność jest szkodliwa dla zdrowia, należy uwzględniać nie tylko prawdopodobne natychmiastowe lub krótkotrwałe skutki tej żywności dla zdrowia spożywającej ją osoby, ale także skutki długofalowe, a nawet skutki dla następnych pokoleń; ewentualne skutki skumulowania toksyczności; a także szczególną wrażliwość określonej kategorii konsumentów, jeżeli żywność jest przeznaczona dla tej kategorii konsumentów. Z kolei przy ocenie przydatności do spożycia przez ludzi należy mieć na względzie, czy żywność nie może być spożywana przez ludzi zgodnie z jej przeznaczeniem z powodu zanieczyszczenia, zarówno przez czynniki obce, jak i w inny sposób, czy też z powodu gnicia, psucia się lub rozkładu.

W przypadku żywności normalnym użyciem jest jej spożywanie. Za niebezpieczną żywność należy więc uznać taką żywność, która nie zapewnia bezpieczeństwa, przy uwzględnieniu faktu, że będzie ona spożywana ${ }^{31}$. Jednakże należy brać pod uwagę zwykłe okoliczności korzystania z żywności przez konsumenta. Przy ustalaniu tych okoliczności należy uwzględnić sposób przyrządzania posiłków i formę ich spożywania (inne zagrożenia związane są z żywnością spożywaną na surowo, a inne z żywnością, która przed spożyciem poddawana jest procesom termicznym) ${ }^{32}$, możliwe łączenie różnych produktów żywnościowych (kumulacja

Przykładowo błędna informacja o dacie przydatności do spożycia może doprowadzić do wystapienia szkody. Ł. Bobeł, K. Leśkiewicz, Odpowiedzialność cywilna za szkodę wyrządzoną przez niebezpieczny środek spożywczy, „Przemysł Spożywczy” 2007, nr 3, s. 39. 
określonych składników może stwarzać zagrożenie), przeciętną częstotliwość spożywania określonych produktów i przeciętną wielkość porcji. Poza tym nie bez znaczenia pozostaje to, do jakiej grupy konsumentów kierowany jest produkt. Wymagany poziom bezpieczeństwa jest oceniany z punktu widzenia odbiorcy produktu (konsumenta), a nie producenta ${ }^{33}$.

Należy zwrócić uwagę, że ustawodawca w sposób szczególny podkreślił wagę prezentacji produktu na rynku oraz objaśnień, informacji i instrukcji, jakie towarzyszą produktowi. Zasady znakowania żywności regulowane są przez szereg przepisów prawa żywnościowego. Podstawowe znaczenie ma regulacja horyzontalna zawarta w dyrektywie 2000/13/WE z dnia 20 marca 2000 r. w sprawie zbliżenia ustawodawstw państw członkowskich w zakresie etykietowania, prezentacji i reklamy środków spożywczych oraz w dyrektywie 90/496/EWG z dnia 24 września 1990 r. w sprawie oznaczania wartości odżywczej środków spożywczych (od 22 listopada $2014 \mathrm{r}$. stosowane będzie w miejsce tych dyrektyw rozporządzenie Parlamentu Europejskiego i Rady nr 1169/2011 z dnia 25 października 2011 r. w sprawie przekazywania konsumentom informacji na temat żywności, zmiany rozporządzeń (WE) nr 1924/2006 i (WE) nr 1925/2006 oraz uchylenia dyrektyw 87/250/EWG, 90/496/EWG, 1999/10/WE, 2000/13/WE, 2002/67/WE, 2008/5/WE i rozporządzenia (WE) nr 608/2004 ${ }^{34}$ ). Oprócz tych aktów istnieje cały szereg regulacji szczegółowych odnoszących się do poszczególnych rodzajów żywności (np. żywność GMO, żywność ekologiczna, suplement diety), specjalnych sposobów oznaczania żywności (oświadczenia zdrowotne i żywieniowe) i niektórych składników żywności. Przy ocenie niebezpieczeństwa produktu żywnościowego należy więc uwzględnić przede wszystkim zgodność oznaczenia żywności z wymaganiami wynikającymi z przepisów prawa. Przykładowo, pominięcie wymaganej przepisami informacji o składniku, który ma właściwości alergenne, może prowadzić nawet do śmierci konsumenta. Istotne jest jednak nie tylko zawarcie wszelkich informacji, ale ważny jest też sposób ich zamieszczenia. Informacja powinna być komunikatywna i czytelna, tj. przedstawiona w języku zrozumiałym dla przeciętnego użytkownika produktu.

Pojęcie prezentacji produktu jest jednak szersze od pojęcia znakowania. Rozumie się przez to także sam sposób opakowania oraz ekspozycji towaru, a także reklamę. Wpływa ona bowiem na opinię konsumenta o produkcie i jego bezpieczeństwie, pełni więc funkcję informacyjną, oprócz promocyjnej ${ }^{35}$. Wszystkie te czynniki mogą wpłynąć na opinię konsumenta o jakości, a zarazem na stopień bezpieczeństwa produktu.

$N^{\circ} 178 / 2002$ on General Food Law, Conclusions of the Standing Committee on the Food Chain and Animal Health, 26 January 2010, s. 9. 
Znamienne jest wprowadzenie domniemania, iż żywność zgodna ze szczegółowymi przepisami unijnymi, a w ich braku krajowymi, regulującymi bezpieczeństwo żywności, jest uważana za bezpieczną pod względem czynników objętych tymi szczegółowymi przepisami (art. 14 ust 7 Ogólnego Prawa Żywnościowego). Oczywiście zgodność z przepisami nie wyłącza odpowiedzialności producenta. Powoduje jednak dodatkowe utrudnienia dowodowe po stronie poszkodowanego, który będzie musiał wykazać, że żywność była niebezpieczna, pomimo, iż była zgodna z obowiązującymi przepisami.

Biorąc pod uwagę zasady oceny niebezpieczeństwa żywności, można stwierdzić, że w tych przypadkach, gdy żywność nie spełniała wymogów przewidzianych przepisami prawa lub była w sposób niewłaściwy oznakowana, nie będzie trudnym wykazanie, iż jest ona niebezpieczna, bowiem nie spełnia owych wymogów, które są ustalone normatywnie. $\mathrm{Z}$ kolei, w tych przypadkach, gdy produkt żywnościowy spełnia wszelkie wymagania prawa żywnościowego i jest należycie oznakowany, dla wykazania niebezpieczeństwa produktu konieczne będzie powołanie się na inne okoliczności, w tym cechy i właściwości produktu występujące w chwili wprowadzenia go do obrotu, które spowodowały, że produkt nie zapewnia bezpieczeństwa, jakiego można oczekiwać, uwzględniając normalne jego użycie.

\section{Producent i inne osoby zobowiązane do wynagrodzenia szkody}

Odpowiedzialność za szkodę wyrządzoną przez produkt niebezpieczny ponosi przede wszystkim producent. Podkreślić należy, że producentem jest wyłącznie osoba wytwarzająca produkt w zakresie swojej działalności gospodarczej. Nie mieszczą się zatem w tej kategorii podmioty, które wprawdzie wytworzyły produkt, ale poza zakresem prowadzonej przez siebie działalności gospodarczej. Nie jest konieczne wytwarzanie produktu w ramach przedsiębiorstwa, pojęcie prowadzenia działalności gospodarczej jest bowiem szersze od pojęcia prowadzenia działalności w ramach przedsiębiorstwa ${ }^{36}$. Samo pojęcie prowadzenia działalności gospodarczej nie jest zdefiniowane w kodeksie cywilnym, jednak pomocniczo wykorzystać można definicję zawartą w ustawie z dnia 2 lipca 2004 r. o swobodzie działalności gospodarczej $^{37}$, w której za działalność gospodarczą uznawana jest zarobkowa działalność, m.in. wytwórcza, wykonywana w sposób zorganizowany i ciągły.

Warto zwrócić uwagę, że w ustawie o swobodzie działalności gospodarczej wskazuje się, że przepisów tej ustawy nie stosuje się do działalności wytwórczej w rolnictwie. W związku z tym wyłączeniem pojawiają się wątpliwości, czy działalność rolnicza jest działalnością gospodarczą. Uznać jednak należy, że wyraźne wyłączenie działalności rolniczej spod reżimu ustawy o swobodzie działalności go-

37 Dz.U. z 2007 r. Nr 155, poz. 1095 ze zm. 
spodarczej świadczy o tym, że tego rodzaju działalność, w związku z tym, że jest prowadzona w celach zarobkowych w sposób zorganizowany i ciągły, jest działalnością gospodarczą, do której nie mają zastosowania przepisy ustawy o swobodzie działalności gospodarczej ${ }^{38}$. W świetle powyższego, biorąc pod uwagę, że produkty żywnościowe pierwotne nie są wyłączone z zakresu definicji produktu, nie budzi najmniejszych wątpliwości, że odpowiedzialność za szkodę wyrządzoną przez produkt niebezpieczny ponosić mogą także rolnicy wytwarzający produkty żywnościowe pierwotne.

Producentem żywności będzie zatem każdy podmiot, który wytwarza żywność w celach zarobkowych w sposób zorganizowany i ciągły. Dla potrzeb ustalenia odpowiedzialności za szkodę wyrządzoną przez produkt niebezpieczny nie ma najmniejszego znaczenia to, czy podmiot taki jest rolnikiem (producentem produktów żywnościowych pierwotnych), czy też producentem żywności przetworzonej. Bez znaczenia jest także to, czy prowadzi działalność o niewielkim zakresie, czy też w większym rozmiarze, nie ma również znaczenia forma prawna prowadzonej działalności.

Podobnie jak producent odpowiada również quasi-producent, tj. osoba podająca się za producenta poprzez umieszczenie na produkcie swojej nazwy, znaku towarowego lub innego oznaczenia odróżniającego: importer oraz wytwórca materiału, surowca albo części składowej produktu (art. $449^{5} \S 1$ i $\$ 2$ kc.). Osoby te odpowiadają solidarnie (art. $449^{5} \S 3 \mathrm{kc}$.), a ewentualne regresy między nimi powinny być rozliczane wedle przepisów regulujących współodpowiedzialność osób za wyrządzenie szkody (art. $441 \S 2 \mathrm{kc}$. w tym przypadku odpowiedzialności opartej na zasadzie ryzyka) $)^{39}$.

Pomocniczo, w sytuacji gdy nie wiadomo, kto jest producentem lub osobą ponoszącą odpowiedzialność solidarnie z producentem, odpowiedzialność ponosi również sprzedawca (art. $449^{5} \S 4$ kc.), co dodatkowo zabezpiecza interesy konsumentów i stwarza im szersze możliwości dochodzenia roszczeń.

Przyjęta regulacja oznacza, że odpowiedzialność za produkt niebezpieczny żywnościowy ponoszona jest przez cztery rodzaje podmiotów:

1) producenta sensu stricto, który produkuje produkt gotowy, surowiec lub część składową;

2) quasi-producenta, który przedstawia się jako producent, umieszczając swą nazwę, znak handlowy lub inną wyróżniającą cechę na produkcie; 
3) importera, który przywozi produkt do Unii Europejskiej w celu sprzedaży w ramach swej działalności gospodarczej;

4) dostawcę dystrybuującego produkt, gdy producenta - lub, w przypadku produktu przywożonego, importera - produktu nie można zidentyfikować i dostawca nie poinformuje o tożsamości producenta lub osoby, która dostarczyla mu produkt, w rozsądnym terminie.

Podkreślenia wymaga fakt, że stosownie do orzecznictwa TSUE pojęcie producenta sensu stricto rozumiane jest w sposób funkcjonalny. Samo formalne przekazanie produktu przez producenta do kolejnego uczestnika obrotu (w przypadku żywności kolejnego etapu łańcucha żywnościowego) nie w każdym przypadku oznacza wprowadzenie produktu do obrotu. Dotyczy to w szczególności sytuacji, gdy pomiędzy producentem i dostawcą zachodzi tak ścisłe powiązanie, że w rzeczywistości dostawca jest włączony w proces produkcji. Dla określenia, czy w istocie nastąpiło przekazanie produktu kolejnemu uczestnikowi łańcucha, istotne jest ustalenie, czy po przekazaniu produktu dostawcy, należącemu formalnie do łańcucha dystrybucji, producent zachował de facto kontrolę nad przekazanym produktem. Jak uznał TSUE, w przypadku gdy producent zachował de facto kontrolę, dostawca uznawany powinien być za producenta produktu ${ }^{40}$. Kwestia przekazania faktycznej kontroli nad produktem musi być jednak każdorazowo rozstrzygana przez sądy krajowe.

Uwagę zwraca szczególnie niekorzystna sytuacja rolnika, który ponosi odpowiedzialność jako producent produktu żywnościowego pierwotnego oraz solidarnie z producentem produktów żywnościowych przetworzonych, jako wytwórca surowca. Co więcej, w produktach żywnościowych pierwotnych szczególnie często występują trudne do wykrycia wady powodowane przez czynniki pozostające poza kontrolą producenta (rolnika), takie jak np. zanieczyszczenie środowiska naturalnego, wzajemne oddziaływanie upraw produktów roślinnych na siebie, przenoszenie się chorób, bakterii, wirusów itd. Rolnik, nawet przy dołożeniu należytej staranności i stosowaniu się do najwyższych standardów dobrej praktyki rolnej, nie jest w stanie w żaden sposób wpływać na te okoliczności zewnętrzne, a nawet bardzo często nie ma możliwości ustalenia zaistnienia takich okoliczności. W przypadku, gdy na wskutek takich okoliczności w produkcie żywnościowym pierwotnym zaistnieją cechy niebezpieczne, producent nie będzie mógł zwolnić się z odpowiedzialności wykazaniem braku swojego zawinienia, a w wielu przypadkach niemożliwe będzie powołanie się na przesłanki egzoneracyjne ani na zaistnienie siły wyższej.

Poza tym należy uwzględnić fakt, że zależności pomiędzy producentami żywności i dystrybutorami stają się coraz bardziej złożone. W wielu przypadkach producenci produktów żywnościowych pierwotnych wytwarzają produkty zgodnie 
z wymaganiami i specyfikacjami nałożonymi na nich umownie przez producentów produktów żywnościowych przetworzonych lub dystrybutorów ${ }^{41}$, co nie wpływa jednak na zakres odpowiedzialności wobec poszkodowanych.

\section{Szkoda}

Odpowiedzialność za produkt obejmuje bez ograniczeń szkody na osobie i w ograniczonym zakresie szkody na mieniu (nie obejmuje szkód polegających na uszkodzeniu samego produktu ani korzyści, jakie poszkodowany mógłby osiągnąć w związku z jego używaniem, ponadto odszkodowanie nie przysługuje, gdy szkoda na mieniu nie przekracza kwoty będącej równowartością 500 euro).

Szkoda na osobie odnosi się bezpośrednio do osoby poszkodowanego. Obejmuje ona uszczerbek polegający na uszkodzeniu ciała, rozstroju zdrowia lub pozbawieniu życia, ewentualnie na naruszeniu innych dóbr osobistych. Uszczerbki te mogą przybrać postać zarówno szkody majątkowej, jak i niemajątkowej (krzywdy).

Biorąc pod uwagę sposób normalnego użycia żywności polegający na jej spożywaniu, podstawowe znaczenie, w odniesieniu do szkód wyrządzonych przez niebezpieczny produkt żywnościowy, mają szkody na osobie. Oznacza to, że o wiele mniejsze znaczenie niż w przypadku szkód wyrządzanych przez inne rodzaje produktów ma ograniczenie odpowiedzialności w odniesieniu do tzw. banalnych szkód na mieniu, których wartość nie przekracza 500 euro. Uznać zatem należy, że ograniczenie to w praktyce nie ogranicza praw osób poszkodowanych przez niebezpieczny produkt żywnościowy.

Szkody na osobie powodowane przez produkty żywnościowe podzielić można na dwie kategorie.

Pierwszy rodzaj to szkody będące bezpośrednim następstwem spożycia konkretnego produktu żywnościowego. Zwykle są to zatrucia wywołane przez bakterie, wirusy i inne drobnoustroje, ewentualnie szkody spowodowane przez przedmioty, które zawarte były w konkretnym produkcie, czy nawet partii produktów.

W tym przypadku stosunkowo łatwo można zlokalizować produkt wyrządzający szkodę. Jednakże podkreślić należy, że w porównaniu do szkód wywoływanych przez innego rodzaju produkty niż żywność, ustalenie niebezpiecznego produktu żywnościowego jest o wiele trudniejsze. Po pierwsze, zwykle spożywa się codziennie wiele produktów żywnościowych pochodzących od wielu producentów i niejednokrotnie wskazanie konkretnego produktu może być utrudnione. Po drugie, powstają też istotne problemy dowodowe. Spożycie produktu żywnościowego i niezachowanie żadnych pozostałości (np. opakowania) oznacza bowiem, iż nie jest możliwe lub też jest bardzo trudne pobranie próbek produktu, co pozwalałoby 
na wskazanie, iż konkretny produkt posiadał właściwości niebezpieczne. Dodatkowy problem związany jest z tym, że nawet w przypadku zachowania pozostałości produktów żywnościowych, zwykle nie są one przechowywane w sposób właściwy dla produktów przeznaczonych do spożycia (np. w określonej temperaturze), nie jest więc możliwe pobranie wiarygodnych próbek. Właściwość niebezpieczna mogła bowiem pojawić się już po spożyciu konkretnego produktu. Kolejny problem dotyczy sytuacji, gdy wprowadzany na rynek środek spożywczy składa się z wielu składników pochodzących od różnych dostawców. W takiej sytuacji ustalenie, który podmiot jest producentem niebezpiecznego składnika, może stwarzać dodatkowe trudności, przy czym problem ten dotyczy wyłącznie wzajemnych rozliczeń pomiędzy uczestnikami łańcucha żywnościowego. Osoba poszkodowana może bowiem dochodzić odszkodowania od producenta produktu finalnego, zatem dla niej nie ma znaczenia, który z podmiotów działających w łańcuchu żywnościowym przyczynił się do powstania niebezpieczeństwa produktu finalnego. $\mathrm{Z}$ tego punktu widzenia szczególnie istotne znaczenie ma prawidłowe funkcjonowaniu systemu identyfikowalności (traceability). System ten powinien umożliwiać odszukanie pochodzenia konkretnego składnika produktu żywnościowego ${ }^{42}$. Podkreślić należy, że im większa jest precyzja i szczegółowość zbieranych informacji oraz bardziej dokładne oznaczanie partii towaru, tym szybciej można ustalić osobę, która ponosi odpowiedzialność.

Kolejny problem dotyczy sytuacji, gdy szkoda powstaje na skutek jednoczesnego spożycia przez poszkodowanego kilku produktów żywnościowych zawierających substancje, pomiędzy którymi zachodzą interakcje mogące powodować szkody lub też sytuacji, gdy określona substancja jest niebezpieczna dla osób dotkniętych określonymi chorobami. W takim przypadku, gdy istniejący stan wiedzy pozwala na przewidzenie zaistnienia reakcji, producent powinien na etykiecie zawrzeć informacje dotyczące potencjalnych zagrożeń, dotyczy to np. substancji wywołujących alergie. Wprowadzenie do obrotu produktu żywnościowego niezawierającego takich informacji uznać należy za wprowadzenie produktu niebezpiecznego. Jeśli natomiast istniejący stan wiedzy nie pozwalał na wykrycie niebezpiecznych reakcji, producenci mogą powołać się na przesłankę egzoneracyjną ryzyka rozwoju.

Drugi rodzaj to szkody, które występują nie bezpośrednio (tj. nie w ciągu kilku godzin czy nawet dni) po spożyciu określonych produktów, ale z dużym opóźczech, w praktyce odnalezienie źródła zagrożenia może przysparzać problemów. Pierwsze informacje o zatruciach zajadliwym szczepem bakterii Eschericha colli (O104:H4) ujawnione zostały przez służby niemieckie 21 maja 2011 r. Początkowo zatrucia wiązano ze spożywaniem świeżych warzyw, wskazywano w szczególności na świeże ogórki pochodzące z Hiszpanii. Jednak prowadzone badania i analiza poszczególnych przypadków zatruć pojawiających się w różnych państwach członkowskich spowodowały, że pod koniec czerwca 2011 r, za najbardziej prawdopodobne źródło zagrożenia uznano partię świeżych kiełków sprowadzonych z Egiptu. Zob. Scientific Report of European Food Safety Authority; Shiga toxin-producing E. coli (STEC) 0104:H4 2011 outbreaks in Europe: Taking Stock. EFSA Journal 2011; 9(10):2390, dostępny na: www.efsa.europa.eu/efsajournal. 
nieniem. Są to szkody wywołane na skutek spożywania przez dłuższy okres czasu określonych środków spożywczych lub produktów zawierających w swoim składzie określone substancje. Szkody te można nazwać szkodami z kumulacji.

Po pierwsze, w tym przypadku niezmiernie trudno jest ustalić związek przyczynowy pomiędzy spożywaniem określonych produktów a występującymi szkodami na osobie. Po drugie, nawet w sytuacji wykazania związku przyczynowego pomiędzy spożywaniem określonych środków spożywczych a zaistniałą szkodą (w związku z powstawaniem nowoczesnych metod diagnostyki leczniczej jest to możliwe), utrudnione jest wskazanie konkretnego podmiotu, który ponosi odpowiedzialność. Określony rodzaj produktów wprowadzają na rynek zwykle różni producenci. Trudno będzie wykazać poszkodowanemu, że spożywał produkty konkretnego producenta, zważywszy, że ten rodzaj szkód wywoływany jest zwykle przez różnego rodzaju substancje, które z kolei dodawane są do różnego rodzaju żywności. Ponadto, jak się wydaje, w wielu przypadkach tego rodzaju szkód, producenci będą mogli powoływać się na przesłankę egzoneracyjną ryzyka rozwoju, a w sytuacji, gdy szkoda ujawni się po upływie dziesięciu lat od wprowadzenia produktu na rynek, producenci będą mogli podnieść zarzut przedawnienia. Mając na względzie ochronę konsumenta, warto byłoby rozważyć powołanie funduszu gwarancyjnego, z którego wypłacane byłyby odszkodowania w przypadku wyrządzenia przez produkt żywnościowy niebezpieczny szkód z kumulacji ${ }^{43}$.

W sytuacji, gdy osoba poszkodowana wykaże fakt istnienia szkody, fakt niebezpieczeństwa konkretnego produktu żywnościowego i związek przyczynowy pomiędzy szkodą i niebezpieczeństwem produktu żywnościowego, może ona uzyskać odszkodowanie, o ile nie zostanie uznane zaistnienie przesłanki egzoneracyjnej. Obowiązek odszkodowawczy w zakresie szkód majątkowych na osobie polegających na uszkodzeniu ciała lub wywołaniu rozstroju zdrowia obejmuje przede wszystkim wszelkie koszty z tego wynikające (takie jak np.: koszty leczenia, pielęg-

Wypłata mogłaby zostać ograniczona wyłącznie do tych przypadków, gdy ustalenie konkretnego producenta byłoby niemożliwe. Tego rodzaju rozwiązanie stosowane jest w kilku państwach w odniesieniu do szkód wyrządzanych przez produkty lecznicze, szkody związane z przetoczeniem zakażonej krwi, szkody powstałe na skutek użycia szczepionki, a nawet w odniesieniu do specyficznych szkód wyrządzonych przez żywność. Fundusze takie dotyczące szkód wyrządzonych przez niebezpieczne produkty lecznicze powołane są w Niemczech, Szwecji, Finlandii (finansowane przez przemysł farmaceutyczny) oraz w Wielkiej Brytanii, Danii (finansowane ze środków publicznych). Powołanie tych funduszy było zwykle następstwem pojawienia się specyficznych szkód związanych z korzystaniem z określonych produktów, przy jednoczesnym braku możliwości pociagnięcia do odpowiedzialności producentów w związku z niemożnością wskazania konkretnego producenta lub powoływaniem się przez nich na ryzyko rozwoju. Zwykle zakres działania tych funduszy jest ograniczony do szczegółowo opisanych rodzajów szkód. Przykładowo w Wielkiej Brytanii, w Niemczech powołano fundusze, z których wypłacane są odszkodowania dla osób, które na skutek spożywania przez ich matki w pierwszym trymestrze ciąży leku o działaniu przeciwwymiotnym (talidomidu) urodziły się z ciężkimi deformacjami ciała. W Hiszpanii powołano fundusz, z którego wypłacane są odszkodowania osobom, które poniosły szkodę na skutek spożycia zatrutego oleju rzepakowego, szkody poniosło ponad 20000 osób. W Wielkiej Brytanii powołany jest także fundusz wypłacający odszkodowania osobom dotkniętym chorobą Creutzfeldta-Jakoba lub członkom ich rodzin. Szerzej zob.: Final Report Analysis of the Economic Impact of the Development Risk Clause as provided by Directive 85/374/ EEC on Liability for Defective Products, Study for the European Commission, Fondazione Rosselli, dostępne na: www.ec.europa.eu 
nacji, odpowiedniego odżywiania oraz koszty dojazdów osób bliskich w celu odwiedzenia poszkodowanego, utracony zarobek, koszty przekwalifikowania art. $444 \S 1$ kc.) oraz zapłatę renty dla wyrównania szkód o charakterze trwałym (utrata zdolności do pracy zarobkowej, zwiększenie potrzeb lub zmniejszenie widoków powodzenia na przyszłość, art. $444 \S 2 \mathrm{kc}$.). Jeżeli wskutek uszkodzenia ciała lub rozstroju zdrowia nastąpiła śmierć poszkodowanego, obowiązek odszkodowawczy obejmuje zwrot kosztów leczenia i pogrzebu temu, kto je poniósł oraz wypłacanie renty na rzecz osób, względem których ciążył na zmarłym ustawowy obowiązek alimentacyjny lub osób bliskich, które zmarły w sposób stały utrzymywał (art. 446 kc.). W zakresie szkód niemajątkowych na osobie naprawienie krzywdy, prócz zwykłych sposobów (np. złożenie oświadczenia woli) może polegać też, w ściśle określonych przypadkach, na pieniężnym zadośćuczynieniu za doznaną krzywdę (art. 445, art. $446 \S 4 \mathrm{kc}.)^{44}$.

\section{E. Przesłanki egzoneracyjne}

Podmiot odpowiedzialny (producent) może uwolnić się od obowiązku wyrównania szkody, jeśli będzie w stanie udowodnić chociaż jedną z kilku przesłanek egzoneracyjnych. Od odpowiedzialności zwalnia go wykazanie, że: (1) nie wprowadził produktu do obrotu, (2) produkt został wprowadzony poza zakresem jego działalności gospodarczej, (3) cecha niebezpieczna nie istniała, gdy wprowadzał produkt do obrotu, (4) zachodzi wyjątkowa sytuacja tzw. ryzyka rozwoju, tzn. że w danym stanie wiedzy i techniki niebezpieczne właściwości produktu nie mogły być znane, (5) właściwości produktu wynikały z konieczności dostosowania się do wymagań prawa. Producent może też uniknąć odpowiedzialności, jeśli wykaże, że przyczyną szkody było wyłącznie działanie osoby trzeciej lub siły wyższej (brak związku przyczynowego z cechami niebezpiecznymi produktu). Ponadto, wytwórca materiału, surowca lub części składowej produktu może uwolnić się od odpowiedzialności, wykazując, że wyłączną przyczyną (związek przyczynowy) szkody była wadliwa konstrukcja produktu finalnego lub wskazówki producenta tego produktu.

W odniesieniu do szkód wyrządzonych przez żywność szczególnie istotne znaczenie mają dwie przesłanki egzoneracyjne, tj. wykazanie, że cecha niebezpieczna nie istniała, gdy producent wprowadzał produkt do obrotu oraz ryzyko rozwoju.

Żywność jest szczególnego rodzaju produktem, może ona nabrać cech produktu niebezpiecznego na każdym etapie łańcucha żywnościowego. Niewłaściwe warunki transportu lub przechowywania mogą skutkować tym, że środek spożywczy sprzedawany konsumentowi jest niebezpieczny, pomimo że w chwili wprowadzania produktu do obrotu przez producenta nie był on produktem niebezpiecznym. 
Ponadto żywność może nabrać cech produktu niebezpiecznego także po sprzedaniu jej konsumentowi, tj. po wyjściu z łańcucha żywnościowego. Dotyczy to w szczególności żywności, która powinna być przechowywana i transportowana w określonej temperaturze. Konsumenci nie zawsze przestrzegają wymogu zapewnienia odpowiedniej temperatury, co wynika chociażby z konieczności transportu żywności ze sklepu do domu, w trakcie którego zwykle nie jest możliwe zapewnienie warunków chłodniczych. Poza tym, do powstania cech niebezpiecznych przyczyniać się może przechowywanie przez konsumentów różnych produktów żywnościowych obok siebie, zbyt długie przetrzymywanie żywności itp.

W przypadku, gdy produkt nie miał cech produktu niebezpiecznego w chwili wprowadzania go do obrotu, producent może zwolnić się z odpowiedzialności, wykazując, że w chwili wprowadzania do obrotu środek spożywczy nie był niebezpieczny. Jednak przeprowadzenie skutecznego dowodu przez producenta może być utrudnione, w szczególności w sytuacji, gdy produkt nabył cech produktu niebezpiecznego po wydaniu go konsumentowi (po wyjściu z łańcucha żywnościowego).

Kluczowe znaczenie ma w tym przypadku określenie momentu wprowadzenia do obrotu. Z orzecznictwa TSUE wynika, że dany produkt jest wprowadzony do obrotu wówczas, gdy opuścił proces produkcji przeprowadzany przez producenta i wszedł do procesu handlowego, w którym jest oferowany odbiorcom w celu użycia lub konsumpcji ${ }^{45}$. W istocie jest to moment utraty faktycznej kontroli nad produktem przez producenta ${ }^{46}$.

Takie rozumienie wprowadzenia do obrotu odbiega od rozumienia pojęcia wprowadzenia na rynek zdefiniowanego w prawie żywnościowym. Zgodnie $\mathrm{z}$ art. 3 pkt 8 Ogólnego Prawa Żywnościowego „wprowadzenie na rynek” oznacza ,posiadanie żywności lub pasz w celu sprzedaży, z uwzględnieniem oferowania do sprzedaży lub innej formy dysponowania, bezpłatnego lub nie, oraz sprzedaż, dystrybucję i inne formy dysponowania". Sam fakt posiadania żywności jest już w świetle tej definicji uznawany za jej wprowadzenie na rynek. Definicja ta nie może być zatem w sposób bezpośredni wykorzystana przy określaniu odpowiedzialności za szkodę wyrządzoną przez produkt niebezpieczny. Dopóki bowiem środek spożywczy jest w posiadaniu producenta (nie nastąpi wydanie produktu), reżim odpowiedzialności za szkodę wyrządzoną przez produkt niebezpieczny nie ma zastosowania. Niewątpliwie natomiast, w przypadku gdy środek spożywczy jest niebezpieczny w momencie wprowadzania go na rynek w znaczeniu nadanym mu w Ogólnym Prawie Żywnościowym, tj. już w momencie posiadania go przez producenta, to tym bardziej będzie on niebezpieczny w chwili wprowadzania go do obrotu, w znaczeniu 
przyjmowanym dla potrzeb określenia odpowiedzialności za produkt, tj. w chwili przekazywania go następnemu uczestnikowi łańcucha żywnościowego.

Drugą istotną przesłanką egzoneracyjną jest tzw. ryzyko rozwoju. Producent może zwolnić się z odpowiedzialności, wykazując, że nie można było przewidzieć niebezpiecznych właściwości produktu, uwzględniając stan nauki i techniki w chwili wprowadzenia produktu do obrotu. Zważywszy na bardzo intensywny rozwój produkcji różnego rodzaju nowej żywności (szczególną uwagę zwraca żywość GMO, żywność wytwarzana z użyciem nanomateriałów oraz nowe suplementy diety), to właśnie ta przesłanka egzoneracyjna (ryzyko rozwoju) ma dla producentów żywności szczególnie istotne znaczenie. Należy podkreślić, że żywność GMO na rynku pojawiła się po raz pierwszy w połowie lat $90^{\prime 47}$. Na rynek nadal wprowadzane są nowe suplementy diety oraz inne środki spożywcze wcześniej nieznane (nowa żywność- novel food). Ponadto wiele składników dodawanych do żywności w celu polepszenia jej smaku, zapachu, wyglądu znalazło zastosowanie w przeciągu ostatnich kilkunastu lat i cały czas pojawiają się nowe. Producenci zamierzający wprowadzić na rynek takie produkty zobowiązani są w oparciu o stosowne przepisy dokonać zgłoszeń lub nawet uzyskać zezwolenie, przedstawiając wymagane informacje o produkcie. Jednak w związku z brakiem danych dotyczących długoletniego stosowania określonych substancji nie można wykluczyć, iż w przyszłości pojawią się negatywne konsekwencje spożywania określonego rodzaju żywności lub konkretnych substancji wchodzących w skład żywności (przykładowo uważa się, że okres obecności GMO w żywności jest zbyt krótki, aby mieć pewność, że negatywne skutki nie ujawnią się po latach ${ }^{48}$.

Podkreślić należy, że w świetle orzecznictwa TSUE ${ }^{49}$ przy powoływaniu się na ryzyko rozwoju należy wziąć pod uwagę obiektywny stan wiedzy naukowej i technicznej, a nie subiektywną wiedzę, jaką posiadał konkretny producent. Co więcej, uwzględniony powinien zostać nie tylko stan wiedzy właściwy dla sektora, w którym działa konkretny producent, ale najbardziej zaawansowany stan wiedzy (most advanced level of knowledge) istniejący w chwili wprowadzania do obrotu. Istotne jest jedynie, by wiedza ta była dostępna w danym momencie.

Ustalone przez TSUE kryteria, które powinny być brane pod uwagę przy powoływaniu się na przesłankę ryzyka rozwoju w praktyce, oznaczają, że wykazanie, iż istniejący stan wiedzy nie pozwalał wykryć niebezpieczeństwa produktu, może być istotnie utrudnione. TSUE nie doprecyzował bowiem, jakiego rodzaju informacje i dane można uznać za najbardziej zaawansowany stan wiedzy istniejący

47 W 1994 r na rynek w USA wprowadzono pomidory FlavrSavr, charakteryzujące się wolniejszym dojrzewaniem i mięknięciem, przez co dłużej zachowywały świeżość i łatwiej można je było transportować. Zob. I. Wrześniewska-Wal, Żywność genetycznie zmodyfikowana, aspekty prawne, Warszawa 2008, s. 18. Ibidem, s. 81.

49 Kluczowe znaczenie ma w tym zakresie wyrok z 29 maja 1995 r. sprawa C-300/95. 
w chwili wprowadzania, co powoduje, iż powstaje bardzo wiele wątpliwości co do rozumienia tej przesłanki ${ }^{50}$. Proces dokonywania odkryć naukowych wymaga obserwacji, analizy, stawiania hipotez, ich potwierdzania, powtarzalności wyników. Powstają zatem pytania, czy wystarczające jest istnienie hipotezy niepotwierdzonej wiarygodnymi badaniami? Nie jest też jasne, jak należy traktować tzw. opinie mniejszościowe? Ponadto niezmiernie trudna z perspektywy czasu jest ocena tego, czy istniejący w chwili wprowadzania produktu stan wiedzy pozwalał przewidzieć niebezpieczne właściwości produktu. Znajomość określonych danych naukowych, które w konsekwencji doprowadziły do wykrycia niebezpiecznej właściwości produktu, niekoniecznie musi oznaczać, że na chwilę wprowadzania produktu do obrotu takie wnioski mogły być wyciągnięte ${ }^{51}$. Biorąc jednak pod uwagę, iż producent nowo wprowadzanych na rynek środków spożywczych zobowiązany jest przedstawić stosowne badania naukowe potwierdzające, że produkt nie jest niebezpieczny ${ }^{52}$ (np. w przypadku żywności GMO), to wykazanie, że w chwili ich wprowadzania na rynek nie posiadały właściwości niebezpiecznych, nie będzie nadmiernie utrudnione. Na korzyść producentów działa także brak obowiązku monitorowania skutków spożywania nowo wprowadzanych produktów żywnościowych (wyjątkiem jest żywność GMO), co powoduje, iż nie ma danych na temat ewentualnie pojawiających się zagrożeń.

\section{F. Przedawnienie roszczeń}

Roszczenie o naprawienie szkody wyrządzonej przez produkt niebezpieczny przedawnia się z upływem trzech lat od dnia, w którym poszkodowany dowiedział się o szkodzie i osobie odpowiedzialnej. W każdym wypadku roszczenie przedawnia się jednak z upływem dziesięciu lat od wprowadzenia produktu do obrotu, bez

Przedłożenie dowodów naukowych jest wymagane jako warunek dopuszczenia do obrotu określonego produktu lub substancji albo ich rodzaju i wynika $z$ aktów prawnych, w których uregulowane zostały zasady dopuszczania do obrotu nowych rodzajów żywności, tj. nowej żywności i żywności GMO oraz nowych rodzajów substancji dodawanych do żywności, tj. dodatków, enzymów, barwników, a także zasady stosowania i dopuszczania nowych oświadczeń żywieniowych i zdrowotnych. Są to przede wszystkim następujące akty prawne: rozporządzenie nr 1829/2003 z dnia 22 września 2003 r. w sprawie genetycznie zmodyfikowanej żywności i paszy (Dz.U. L 268 z 18.10.2003, s. 1); rozporządzenie nr 258/97 z dnia 27 stycznia 1997 r. dotyczące nowej żywności i nowych składników żywności (Dz.U. UE L 43 z 14.2.1997, s. 1); rozporządzenie nr 1331/2008 z dnia 16 grudnia 2008 r. ustanawiające jednolitą procedurę wydawania zezwoleń na stosowanie dodatków do żywności, enzymów spożywczych i środków aromatyzujących (Dz.U. UE L 354 z 31.12.2008, s. 1); rozporządzenie nr 1333/2008 z dnia 16 grudnia 2008 r. w sprawie dodatków do żywności (Dz.U. UE L 354 z 31.12.2008, s. 16); rozporządzenie nr 1332/2008 z dnia 16 grudnia 2008 r. w sprawie enzymów spożywczych, zmieniające dyrektywę Rady 83/417/EWG, rozporządzenie Rady (WE) nr 1493/1999, dyrektywę 2000/13/WE; dyrektywa Rady 2001/112/WE oraz rozporządzenie (WE) nr 258/97 (Dz.U. UE L 354 z 31.12.2008, s. 7); rozporządzenie nr 1334/2008 z dnia 16 grudnia 2008 r. w sprawie środków aromatyzujących i niektórych składników żywności o właściwościach aromatyzujących do użycia w oraz na środkach spożywczych oraz zmieniające rozporządzenie Rady (EWG) nr 1601/91, rozporządzenie (WE) nr 2232/96 oraz (WE) nr 110/2008 oraz dyrektywę 2000/13/WE (Dz.U. UE L 354 z 31.12.2008, s. 34); rozporządzenie $\mathrm{nr}$ 1925/2006 z dnia 20 grudnia 2006 r. w sprawie dodawania do żywności witamin i składników mineralnych oraz niektórych innych substancji (Dz.U. UE L 404 z 30.12.2006, s. 26); rozporządzenie nr 1924/2006 z dnia 20 grudnia 2006 r. w sprawie oświadczeń żywieniowych i zdrowotnych dotyczących żywności (Dz.U. UE L 404 z 30.12.2006, s. 9). 
względu na to, kiedy szkoda powstała lub się ujawniła. Gdy do powstania szkody lub jej ujawnienia doszło później niż po upływie dziesięciu lat od dnia, w którym nastąpiło wprowadzenie produktu do obrotu, osoba obowiązana do naprawienia szkody może skutecznie uchylić się od obowiązku odszkodowawczego przez podniesienie zarzutu przedawnienia.

Ustanowienie dziesięcioletniego okresu przedawnienia, niezależnego od ujawnienia się, a nawet powstania szkody, budzi wątpliwości, w szczególności w odniesieniu do roszczeń o naprawienie szkody na osobie wyrządzonej przez produkt niebezpieczny ${ }^{53}$.

Nie ulega wątpliwości, że nie mogą w systemie prawnym istnieć unormowania, które umożliwiają dochodzenie praw czy ich wykonywanie z jednoczesnym nałożeniem na inne podmioty obowiązków im odpowiadających ad infinitum, przez czas nieokreślony oraz takie, które powodują permanentny stan niepewności co do rzeczywistego stanu prawnego. W przypadku przedawnienia roszczeń o odszkodowanie z tytułu szkody wyrządzonej przez produkt niebezpieczny problem polega jednak na tym, że sam mechanizmu obliczania terminu przedawnienia skutkuje tym, że przedawnienie może nastąpić przed ujawnieniem się szkody, a więc przed momentem w którym poszkodowany mógłby podjąć jakiekolwiek działania.

Rozwój nauk przyrodniczych i wprowadzanie coraz to nowych technologii i rozwiązań technicznych w produkcji powoduje $z$ jednej strony, iż powstają nieznane i trudne do wykrycia zagrożenia związane z korzystaniem z określonych produktów, a z drugiej strony powstają też możliwości precyzyjnego wykrywania szkód na osobie i powiązania ich ze zdarzeniem, które mogło mieć miejsce w odległej przeszłości (w dzieciństwie, a nawet w życiu prenatalnym). W sposób szczególny dotyczy to przyjmowania produktów leczniczych, ale może dotyczyć także spożywania określonego rodzaju żywności, w szczególności suplementów diety. W razie ujawnienia się szkody po wielu latach od wprowadzenia produktu do obrotu, w tych przypadkach, gdy przesłanka egzoneracyjna ryzyka rozwoju nie będzie mogła mieć zastosowania, to właśnie sztywny dziesięcioletni okres przedawnienia skutkował będzie brakiem możliwości dochodzenia roszczeń z wykorzystaniem reżimu odpowiedzialności za szkodę wyrządzoną przez produkt niebezpieczny.

Warto zauważyć, że szkody na osobie mają szczególny charakter, są ściśle związane z psychofizycznymi właściwościami każdej osoby. Chodzi bowiem nie o uszczerbek w określonych dobrach majątkowych osoby, lecz o samą osobę. Uszczerbek na osobie zwykle ma, przynajmniej pośredni, wpływ na życie osoby po-

TK uznał za nie zgodny z Konstytucją art. 442 § 1 zdanie drugie ustawy z dnia 23 kwietnia 1964 r. - Kodeks cywilny przez to, że pozbawia pokrzywdzonego dochodzenia odszkodowania za szkodę na osobie, która ujawniła się po upływie lat dziesięciu od wystapienia zdarzenia wyrządzającego szkodę, wyrok TK z dnia 1 września 2006 r., sygn. akt SK 14/05. 
szkodowanej w wielu jego wymiarach, takich jak możliwości rozwoju zdolności, realizacji aspiracji i ambicji, czy po prostu możliwości uzyskania środków utrzymania ${ }^{54}$. Warto też zwrócić uwagę, że regulacja prawna odpowiedzialności za szkodę wyrządzoną przez produkt niebezpieczny w tej części, w jakiej dotyczy szkód na osobie, wpisuje się w grupę regulacji nakierowanych na ochronę godności człowieka. Ochrona zdrowia jest bowiem ściśle związana z ochroną życia, a prawo do życia z godnością człowieka. Prawo do ochrony zdrowia to przede wszystkim prawo do zachowania życia i jego obrony, gdy jest zagrożone ${ }^{55}$. Poza tym, regulacja odpowiedzialności za produkt w zakresie dotyczącym szkód na osobie w sposób najpełniejszy wpisuje się w cele prawa żywnościowego. Ten szczególny charakter szkód na osobie powinien skłaniać do odmiennego traktowania czynów niedozwolonych, wywołujących tego typu szkody ${ }^{56}$.

Jak się wydaje, instytucja przedawnienia roszczeń majątkowych w istocie chroni głównie interes producenta (dłużnika), a nie poszkodowanego (wierzyciela). Nie tylko jednak dłużnik ma interes w tym, aby jego niepewność co do istnienia obowiązku świadczenia była ograniczona w czasie, a ustanie tej niepewności dało się określić na podstawie jednoznacznych, obiektywnych mierników. Ograniczenie takie służy przede wszystkim stabilności i pewności stosunków społecznych, co jest podstawowym celem instytucji przedawnienia ${ }^{57}$.

Przyjęcie sztywnego dziesięcioletniego terminu przedawnienia jest uzasadniane głównie tym, że odpowiedzialność niezależna od winy stanowi dla producenta zdecydowanie większe obciążenie niż odpowiedzialność oparta na tradycyjnych zasadach odpowiedzialności.

Prawodawca uznał, że ograniczenie w czasie odpowiedzialności niezależnej od winy poprzez ustalenie jednolitej i stałej w całej Unii końcowej daty, po której producent nie ponosi odpowiedzialności bez konieczności wykazywania jakichkolwiek przesłanek egzoneracyjnych, jest konieczne po to, aby ten nowy reżim odpowiedzialności nie stanął na drodze postępowi technicznemu, aby producent mógł oszacować dodatkowe obciążenie wynikające z nowego reżimu odpowiedzialności i aby możliwe było pokrycie ryzyka odpowiedzialności przez ubezpieczycieli ${ }^{58}$. Przyjęcie sztywnego dziesięcioletniego okresu przedawnienia jest wyrazem rozłożenia ryzyka pomiędzy producentów, uzyskujących zyski w związku ze sprzedażą produktów, a konsumentów, będących beneficjentami nowych rozwiązań.

Wyrok TK z dnia 7 stycznia 2004 r. sygn. K 14/03.

T. Dybowski, Glosa do wyroku SN 21 maja 2003, sygn IV CKN 378/01, „Przegląd Sądowy” 2005, nr 6, s. 136137. 
W związku z tym, że osoba poszkodowana może dochodzić odszkodowania na podstawie reżimu ex delicto, gdzie w razie szkody na osobie przedawnienie nie może skończyć się wcześniej niż z upływem lat trzech od dnia, w którym poszkodowany dowiedział się o szkodzie i o osobie obowiązanej do jej naprawienia (art. 442 $\S 3 \mathrm{kc}$.), przyjęte rozwiązanie uznać należy za uzasadnione.

\section{G. Funkcje odpowiedzialności za szkodę wyrządzoną przez produkt niebezpieczny}

Co do zasady odpowiedzialność cywilna realizuje przede wszystkim funkcję kompensacyjną ${ }^{59}$. Jednak jak podkreślał prof. A. Stelmachowski, charakterystyczną cechą tej odpowiedzialności jest jej kompleksowość, realizuje ona trzy podstawowe funkcje: kompensacyjną, penalną (represyjną), wychowawczo-prewencyjną ${ }^{60}$.

Wprowadzenie reżimu odpowiedzialności za szkodę wyrządzoną przez produkt niebezpieczny żywnościowy, nie tylko przyczynia się do lepszej realizacji funkcji kompensacyjnej, ale wpływa na zachowania producentów, a więc realizuje funkcje prewencyjno-wychowawczą.

Funkcja prewencyjno-wychowawcza realizowana jest przede wszystkim w tych przypadkach, gdy odpowiedzialność oparta jest na zasadzie winy. Funkcja ta realizowana może być także wtedy, gdy co prawda odpowiedzialność nie jest oparta na zasadzie winy, jednak podmiot, który w przyszłości może ponieść odpowiedzialność ma możliwość poprzez swoje zachowanie ograniczyć prawdopodobieństwo wystąpienia szkody w przyszłości, np. poprzez wprowadzenie usprawnień techniczno-organizacyjnych ${ }^{61}$.

Sam fakt obowiązywania przepisów określających zasady odpowiedzialności za szkodę wyrządzoną przez produkt niebezpieczny stanowi istotną motywację do pełnego przestrzegania przez uczestników łańcucha żywnościowego przepisów prawa żywnościowego i do wzmożonej staranności, w tym do bieżącego monitorowania wiedzy naukowej w zakresie dotyczącym prowadzonej przez dany podmiot działalności, co niewątpliwie wywiera korzystny wpływ nie tylko na bezpieczeństwo, ale i na jakość produktów żywnościowych.

Podkreślić należy, że w świetle celów prawa żywnościowego to właśnie funkcja prewencyjno-wychowawcza, a nie kompensacyjna ma szczególne znaczenie. Funkcja prewencyjna odpowiedzialności odszkodowawczej w sposób najpełniejszy łączy się z realizacją celów prawa żywnościowego. Dlatego też reżim odpowiedzialności

59 W. Czachórski, Zobowiazania..., s. 96.

60 A. Stelmachowski, Zarys teorii prawa cywilnego, Warszawa 1998, s. 213; W. Radecki, Odpowiedzialność prawna w ochronie środowiska, Warszawa 2002, s. 82.

61 Tak A Śmieja, Z problematyki funkcji odpowiedzialności odszkodowawczej, (w:) Prace cywilistyczne, Warszawa 1990, s. 332, w odniesieniu do odpowiedzialności odszkodowawczej ponoszonej na zasadzie ryzyka. 
za produkt niebezpieczny dodatkowo motywuje podmioty działające na rynku spożywczym do przestrzegania przepisów prawa żywnościowego (w tym liczenia się z możliwością zastosowania zasady ostrożności) oraz śledzenia wiedzy naukowej.

W związku z powyższym widoczna jest niekonsekwencja ustawodawcy. Z jednej bowiem strony w art. 17 Ogólnego Prawa Żywnościowego wskazuje się, że „,podmioty działające na rynku spożywczym i pasz zapewniają, na wszystkich etapach produkcji, przetwarzania i dystrybucji w przedsiębiorstwach będących pod ich kontrolą, zgodność tej żywności lub pasz z wymogami prawa żywnościowego właściwymi dla ich działalności i kontrolowanie przestrzegania tych wymogów”. Biorąc pod uwagę, że ,podmioty działające na rynku spożywczym” są to „osoby fizyczne lub prawne odpowiedzialne za spełnienie wymogów prawa żywnościowego w przedsiębiorstwie spożywczym pozostającym pod ich kontrolą”, a „przedsiębiorstwo spożywcze” jest to ,przedsiębiorstwo publiczne lub prywatne, typu non-profit lub nie, prowadzące jakąkolwiek działalność związaną z jakimkolwiek etapem produkcji, przetwarzania i dystrybucji żywności”, wnioskować należy, że wszelkie podmioty działające w sektorze żywnościowym, na dowolnym etapie łańcucha żywnościowego, zobowiązane są do przestrzegania wymogów prawa żywnościowego.

Z drugiej strony, pomimo że przepisy prawa żywnościowego wprost odsyłają do przepisów określających odpowiedzialność za szkodę wyrządzoną przez produkt niebezpieczny, co niejako potwierdza, iż to właśnie ten reżim odpowiedzialności w sposób najpełniejszy przyczynia się do realizacji celów prawa żywnościowego, to odpowiedzialność opartą o ten reżim ponosić mogą jedynie producenci. Zatem ograniczona jest ona do jednego z etapów łańcucha żywnościowego. Stan taki powoduje, że nie jest uwzględniona specyfika produktu żywnościowego, polegająca na tym, że cecha niebezpieczna może pojawić się na każdym etapie łańcucha żywnościowego. Zasadnym byłoby zatem wprowadzenie subsydiarnej odpowiedzialności sprzedawcy w tych przypadkach, gdy cecha niebezpieczna pojawiła się po wprowadzeniu produktu żywnościowego do obrotu przez producenta, co w konsekwencji zwalnia z odpowiedzialności producenta. W świetle obecnie obowiązujących przepisów sprzedawca ponosi odpowiedzialność subsydiarną, w sytuacji gdy nie jest możliwe ustalenie producenta, co chroni konsumentów w szczególnym przypadku braku możliwości dochodzenia odszkodowania od producenta. Wprowadzenie drugiego przypadku ponoszenia odpowiedzialności przez sprzedawcę przyczyniłoby się do zapewnienia lepszej ochrony konsumentom, którzy mogliby dochodzić odszkodowania od sprzedawcy dopiero wtedy, gdy producent wykazałby, iż nie ponosi odpowiedzialności w związku z brakiem cechy niebezpiecznej w chwili wprowadzania produktu żywnościowego do obrotu. Sprzedawca jednocześnie mógłby dochodzić odszkodowania od pozostałych uczestników łańcucha żywnościowego (np. od przewoźnika, który nie zapewnił odpowiedniej temperatury w czasie transportu z hali producenta do sieci handlowej). 


\section{Podsumowanie}

Wyraźne odwołanie w podstawowym dla prawa żywnościowego Unii Europejskiej akcie prawnym - Ogólnym Prawie Żywnościowym - do reżimu odpowiedzialności za szkodę wyrządzoną przez produkt niebezpieczny stanowi sugestię, iż to właśnie ten reżim odpowiedzialności powinien mieć kluczowe znaczenie w przypadku szkód powodowanych przez żywność niebezpieczną.

Niewątpliwą zaletą tego reżimu odpowiedzialności jest to, że osoba poszkodowana nie jest zobowiązana do wykazania winy producenta, wystarczające jest wykazanie faktu zaistnienia szkody, faktu, iż środek spożywczy był niebezpieczny oraz związku przyczynowego pomiędzy zaistniałą szkodą i niebezpiecznymi właściwościami żywności. Oparcie tej odpowiedzialności na zasadzie ryzyka stanowi ułatwienie dla konsumentów. Jednocześnie takie ukształtowanie odpowiedzialności stanowi dodatkowe obciążenie dla producentów, którzy nie mogą zwolnić się z odpowiedzialności nawet przez wykazanie, iż dołożyli należytej, a nawet ponadstandardowej staranności przy wytwarzaniu żywności. Jakkolwiek ustalono określone przesłanki uwolnienia się od tego rodzaju odpowiedzialności, nie stworzono jednakże w prawie unijnym (dyrektywa 85/374) konstrukcji odpowiedzialności absolutnej.

Okoliczność, że odpowiedzialność za produkt niebezpieczny nie ma charakteru absolutnego wespół z ustanowieniem sztywnego okresu przedawnienia, niezależnego od momentu, w którym szkoda zaistniała lub została ujawniona, stworzyło mechanizm będący przeciwwagą dla niezależnej od winy odpowiedzialności producenta, mający na celu wyważenie interesów producentów i konsumentów.

Poza początkowym okresem obowiązywania dyrektywy 85/374, w którym istniała możliwość wykluczenia z kategorii produktów, a w konsekwencji z zakresu tego nowego reżimu odpowiedzialności produktów żywnościowych pierwotnych, nie zostały przewidziane żadne szczególne reguły dotyczące odpowiedzialności za szkody wyrządzone przez produkt niebezpieczny żywnościowy.

Ustawodawca unijny nie uwzględnił specyfiki produktu, jakim jest żywność (ani też żadnego innego produktu, np. produktu leczniczego) i szczególnego charakteru szkód, jakie mogą powstawać na skutek spożywania żywności.

$\mathrm{Z}$ jednej strony, trudności dowodowe powodują, że ten reżim odpowiedzialności w praktyce może być wykorzystywany głównie w tych przypadkach, gdy szkoda stanowi bezpośrednie następstwo spożycia określonego środka spożywczego (np. zatrucie pokarmowe). Z kolei w bardzo ograniczonym zakresie może okazać się przydatny w tych sytuacjach, gdy szkoda ujawni się po dłuższym czasie spożywania żywności (na skutek kumulacji). Producent będzie mógł wówczas powołać się na przesłankę egzoneracyjną w postaci ryzyka rozwoju, a ponadto roszczenie ulega przedawnieniu z upływem dziesięciu lat od wprowadzenia produktu do obrotu. 
Zwraca uwagę szczególnie niekorzystna sytuacja rolnika, który jako producent produktu żywnościowego pierwotnego ponosi odpowiedzialność za szkody wyrządzone przez produkt niebezpieczny nawet wtedy, gdy cecha niebezpieczna produktu powstała na skutek okoliczności, na które, zachowując należytą staranność, nie ma on żadnego wpływu. Ma to szczególnie często miejsce w przypadku produktów żywnościowych pierwotnych, gdy niebezpieczna właściwość produktu może pojawić się ze względu na stan środowiska naturalnego, rodzaj upraw prowadzonych na sąsiednich nieruchomościach itp.

Jednocześnie widoczna jest niekonsekwencja ustawodawcy, który z jednej strony w Ogólnym Prawie Żywnościowym na wszystkie podmioty działające na rynku spożywczym na wszystkich etapach łańcucha żywnościowego nakłada obowiązek przestrzegania wymogów prawa żywnościowego, a z drugiej strony wprost w tym akcie prawnym odsyła do reżimu odpowiedzialności za produkt niebezpieczny, która zasadniczo odnosi się wyłącznie do producenta. Zatem ten rodzaj odpowiedzialności nie może realizować funkcji prewencyjnej w odniesieniu do podmiotów działających na rynku spożywczym innych niż producenci, co jest szczególnie niekorzystne, uwzględniając fakt, że właściwości niebezpieczne produktu żywnościowego zaistnieć mogą na każdym etapie obrotu. Osoby poszkodowane nie mogą korzystać z tej uproszczonej metody dochodzenia odszkodowania od przedsiębiorcy, który umiejscowiony jest w łańcuchu żywnościowym na dalszym etapie niż produkcja, nawet jeśli to jego działania lub zaniechania spowodowały, iż produkt uzyskał właściwości niebezpieczne.

W przypadku, gdy szkoda powstanie lub ujawni się po upływie dziesięciu lat od wprowadzenia produktu do obrotu, osoba, która doznała szkody, nie będzie mogła dochodzić odszkodowania. Biorąc jednak pod uwagę, że osoba taka po upływie tego okresu przedawnienia będzie mogła dochodzić odszkodowania na podstawie pozostałych reżimów odpowiedzialności, uznać należy, że przyjęte rozwiązanie jest uzasadnione. W szczególności zważywszy na to, że przyczynia się to do stabilności i pewności stosunków społecznych.

Podsumowując, stwierdzić należy, że wbrew założeniu leżącemu u podstaw wyraźnego odwołania się w prawie żywnościowym do regulacji odpowiedzialności za szkodę wyrządzoną przez produkt niebezpieczny, zgodnie z którym ma nastąpić uproszczenie i ułatwienie dochodzenia odszkodowania z tytułu szkód wyrządzonych przez produkty niebezpieczne żywnościowe, przy jednoczesnym uwzględnieniu interesu producentów, nieuwzględnienie specyfiki unikatowego produktu, jakim jest żywność, powoduje, że reżim ten w niewielkim tylko stopniu ułatwia dochodzenie roszczeń konsumentom żywności.

Regulacja odpowiedzialności za szkodę wyrządzoną przez produkt niebezpieczny wymagałaby zatem modyfikacji w odniesieniu do produktu żywnościo- 
wego, uwzględniającej zarówno cechy żywności i skali obrotu tym produktem, jak również sytuacji prawnej podmiotów działających na rynku spożywczym, poczynając od producenta pierwotnego, którego działalność zgodnie z Ogólnym Prawem Żywnościowym jest pierwszym etapem produkcji w łańcuchu żywnościowym. 


\section{Liability for defective food product unprocessed and processed selected issues}

Key words: damage, food product, agricultural producer

In accordance with food law liability for defective product is essential to seek damages, in the case of damage caused by the food. In the article the author presents several issues concerning liability for defective food product.

Food is characterized by the fact that inappropriate transport or storage conditions may cause the food becomes unsafe at each stage of the food chain. This means that the producer relatively easy may release himself from liability. At the same time, under this regime of liability, any other operator of the food chain is not responsible in that case.

Additionally, it is provided for ten year limitation period, starting from the product launch, independent of the point where damage occurs.

Moreover, the situation of agricultural producer is unfavorable. Very often it is impossible to detect the dangerous qualities of the unprocessed food. In addition, unprocessed food becomes dangerous due to the circumstances in which the farmer has no impact (e.g. pollution).

The author concludes that the legislator, establishing rules for product liability, has not taken into account the specific features of food product. As the result of the above the protection of the consumer on the basis of this regime of liability is not sufficient but on the other hand the liability of farmer is too strict. 